\title{
Occurrence and Sources of Synthetic Musk Fragrances in the Sewage Treatment Plants and the Han River, Korea
}

\author{
Ju-Hee Hong ${ }^{1}$, Jun-Yeon Lee ${ }^{1}$, Hyun-Ju Ha ${ }^{1}$, Jin-Hyo Lee ${ }^{1}$, Seok-Ryul Oh ${ }^{1}$, Young-Min Lee ${ }^{2}$, Mok-Young Lee ${ }^{1, *}$ \\ and Kyung-Duk Zoh ${ }^{2, *}$ (D) \\ 1 Department of Water Environment Research, Seoul Metropolitan Government Research Institute of Public \\ Health and Environment, Seoul 13818, Korea; ghdghd@seoul.go.kr (J.-H.H.); kdzoh94@gmail.com (J.-Y.L.); \\ angelaha@seoul.go.kr (H.-J.H.); jinhyo@korea.kr (J.-H.L.); seokryul@seoul.go.kr (S.-R.O.) \\ 2 Department of Environmental Health Sciences, School of Public Health, Seoul National University, \\ Seoul 08826, Korea; ubyong@snu.ac.kr \\ * Correspondence: mylee9@seoul.go.kr (M.-Y.L.); zohkd@snu.ac.kr (K.-D.Z.)
}

Citation: Hong, J.-H.; Lee, J.-Y.; Ha, H.-J.; Lee, J.-H.; Oh, S.-R.; Lee, Y.-M.; Lee, M.-Y.; Zoh, K.-D. Occurrence and Sources of Synthetic Musk Fragrances in the Sewage Treatment Plants and the Han River, Korea. Water 2021, 13, 392. https://doi.org/10.3390/ w13040392

Academic Editor: Miren López de Alda Villaizán

Received: 28 December 2020

Accepted: 27 January 2021

Published: 3 February 2021

Publisher's Note: MDPI stays neutral with regard to jurisdictional claims in published maps and institutional affiliations.

Copyright: (c) 2021 by the authors. Licensee MDPI, Basel, Switzerland. This article is an open access article distributed under the terms and conditions of the Creative Commons Attribution (CC BY) license (https:// creativecommons.org/licenses/by/ $4.0 /)$.

\begin{abstract}
Levels of synthetic musk fragrances (SMFs) and various personal care products (PCPs) were measured in the Han River and its tributaries in Seoul, Korea. The most abundant SMF in all river and PCP samples was 4,6,6,7,8,8-hexamethyl-1,3,4,7-tetrahydrocyclopenta(g)sochromene (HHCB), followed by 1-(3,5,5,6,8,8-hexamethyl-6,7-dihydronaphthalen-2-yl)ethanone (AHTN), musk ketone (MK), and 1,1,2,3,3-pentamethyl-2,5,6,7-tetrahydroinden-4-one (DPMI). The most abundant SMF in both PCPs and the Han River samples was HHCB, followed by AHTN. Moving from upstream to downstream in the Han River, the median SMF concentration was 6.756, 2.945, 0.304, and $0.141 \mu \mathrm{g} / \mathrm{L}$ in the sewage treatment plant (STP) influents, effluents, tributaries, and mainstream, respectively, implying that effective SMF removal was achieved during the sewage treatment process, followed by dilution in the receiving water. Four STPs using advanced biological treatment processes had removal efficiencies of $58.5 \%, 56.8 \%$, and $38.1 \%$ for HHCB, AHTN, and MK, respectively. The highest SMF concentrations in the tributaries were observed at locations close to the STPs. Our study confirmed that the main source of SMFs in the receiving water were sewage effluents containing untreated SMFs, which largely originate from household PCPs, especially hair care products (e.g., shampoo) and perfumes.
\end{abstract}

Keywords: AHTN; HHCB; musk ketone; personal care product; sewage treatment plant; synthetic musk fragrance

\section{Introduction}

Synthetic musk fragrances (SMFs) are synthetic aromatic compounds that are used in the perfume industry to mimic the scent of deer and other animals [1,2]. Synthetic musks are categorized as nitro, macrocyclic, polycyclic, or alicyclic musk according to their chemical structure and the synthesis methods [3,4]. Nitro musk was synthesized by Baur in 1888, but its use is now restricted due to its proven harmful effects on humans and the environment [5,6]. Macrocyclic musk is difficult to synthesize, and expensive, because it has a complex chemical structure. In contrast, polycyclic musk is relatively inexpensive to synthesize and is known to be safer than nitro musk; it accounts for more than $90 \%$ of all synthetic musk used currently [2,7].

The amount of polycyclic musk used in Korea in 2006 was reported to be 60.6 tons for 4,6,6,7,8,8-hexamethyl-1,3,4,7-tetrahydrocyclopenta(g)isochromene (HHCB) and 2 tons for 1-(3,5,5,6,8,8-hexamethyl-6,7-dihydronaphthalen-2-yl)ethanone (AHTN). The most commonly used nitro musks are musk ketone (MK; 1-(4-tert-butyl-2,6-dimethyl-3,5-dinitrophenyl) ethanone) and musk xylene (MX;1-tert-butyl-3,5-dimetyl-2,4,6-trinitrobenzene; 11.6 and 0.9 tons of these musks were used in 2006, respectively [8,9]. This indicates that on a volume basis, polycyclic musk is more widely used than nitro musk in Korea. Given that the 
total amount of chemical substances used in 2016 increased by 40\% compared to 2010 [10], the amount of SMFs used in personal care products (PCPs) might now be much more than in 2006 when the survey was originally conducted. The annual usage of HHCB increased by more than six times in 2016 compared to 2006 [11].

Because SMFs are difficult to chemically degrade, they can persist in the environment. Synthetic musk fragrances are also lipophilic, so they can accumulate in the adipose tissues of humans and aquatic animals. Several researchers have raised concerns about the safety of HHCB and AHTN following their detection in human fat cells, milk, and even breast milk $[7,12]$. Other studies have confirmed that nitro musk can act as a weak endocrine disruptor [6]. In a rat study, it was also confirmed that nitro musk compounds can increase the incidence of various cancers, and their toxicity is enhanced when they are present together with other toxic substances, such as benzo-a-pyrene [6]. Additionally, Xenobiotic metabolism on fish, estrogenic effect on zebrafish, and acute toxicity on medaka by SMFs have been reported [13-15]. Therefore, the European Chemical Agency has determined the predicted no effect concentration (PNEC) values for the aqueous phase (PNECwater) for several SMFs (HHCB, $4.4 \mu \mathrm{g} / \mathrm{L}$; AHTN, $2.8 \mu \mathrm{g} / \mathrm{L} ; \mathrm{MX}, 1.1 \mu \mathrm{g} / \mathrm{L}$; and MK, $1.0 \mu \mathrm{g} / \mathrm{L}$ ) [16-19]. The United States Environmental Protection Agency (US EPA) also lists SMFs on the inventory list of the Toxic Substances Control Act (TSCA) because they have negative effects on human health and the environment, including endocrine-disrupting effects [20]. Musk xylene, HHCB, and AHTN are included in the Substances of Very High Concern (SVHC) list as very persistent and very bioaccumulative (vPvB) substances. The European Chemicals Agency (ECHA) has classified HHCB as an acute and chronic aquatic toxic substance, while MX and MK have been classified as acute and chronic aquatic toxic substances and carcinogens [21]. It is therefore important to determine the levels, and the fate and behavior, of SMFs in the aquatic environment.

Because SMFs are widely used as scented raw materials in household PCPs, more than $90 \%$ of the total amount of SMFs used in households enters domestic sewage treatment plants (STPs). Untreated SMFs in STPs can contaminate surface waters through STP effluents. The SMF concentrations in the receiving water can be affected by the sewage treatment process and their removal efficiencies in STPs. Several studies have reported the occurrence of SMFs in sewage effluents in several STPs $[7,22-26]$. The SMF removal efficiencies in STPs varied from $50 \%$ to $90 \%$ [25,27-29]. Reiner et al. [30] also reported that HHCB was detected in the concentration range of 1.78-12.7 $\mu \mathrm{g} / \mathrm{L}$ in the influent from an urban STP located in New York State, while in a sewage influent in rural Kentucky it was present in the range of $0.043-7.032 \mu \mathrm{g} / \mathrm{L}$.

Surface water monitoring results of SMFs have been reported in other parts of Korea $[8,25,31]$, but no survey has been conducted in the Han River, which passes through Seoul metropolitan area. Therefore, the aims of this study are (a) to measure the SMF levels in STP influents, effluents, the mainstream of the Han River, and its tributaries; (b) to compare the SMF levels in the Han River samples with the levels found in PCPs; and (c) to assess the possible sources and discuss the major removal mechanisms of SMFs in the Han River.

\section{Materials and Methods}

\subsection{Chemicals}

Nine SMF substances were selected for study based on the global usage rates and toxicity values of SMFs, including six polycyclic musks: 1-(6-tert-butyl-1,1-dimethyl-2,3dihydroinden-4-yl)ethanone (ADBI), 1-(1,1,2,6-tetramethyl-3-propan-2-yl-2,3-dihydroinden5-yl)ethanone (ATII), 1-(1,1,2,3,6-hexamethyl -2H-indene-5-yl)ethanone (AHMI), AHTN, 1,1,2,3,3-pentamethyl-2,5,6,7-tetrahydroinden-4-one (DPMI), and HHCB; and three nitro musks: 1-tert-butyl-2-methoxy-4-methyl-3,5-dinitrobenzene (musk ambrette; MA), MX, and MK $[5,6]$.

The physicochemical properties of the selected SMFs are presented in Table 1. Certified analytical grade SMF standards were purchased from Dr. Ehrenstorfer GmBH (Augsburg, 
Germany), and an internal standard, fluoranthene-d10, was purchased from Chiron (Trondheim, Norway). Acetone and water (HPLC grade) were purchased from Thermo Fisher Scientific (Waltham, MA, USA) and $\mathrm{NaCl}(>99 \%)$ from Tedia (Fairfield, CT, USA).

\subsection{Sampling}

Surface water samples were collected every month from March to November 2018 from five main streams of the Han River (H1-H5) and 17 sites in its tributaries (T1-T17) (Figure 1). The Han River is the largest river in South Korea. It flows through Seoul and has three large tributaries, with various small streams; the average flow is about $874 \mathrm{~m}^{3} / \mathrm{s}$. Surface water samples were collected using pre-washed glass bottles (2 L volume) that were stored in a cool dark location before analysis.

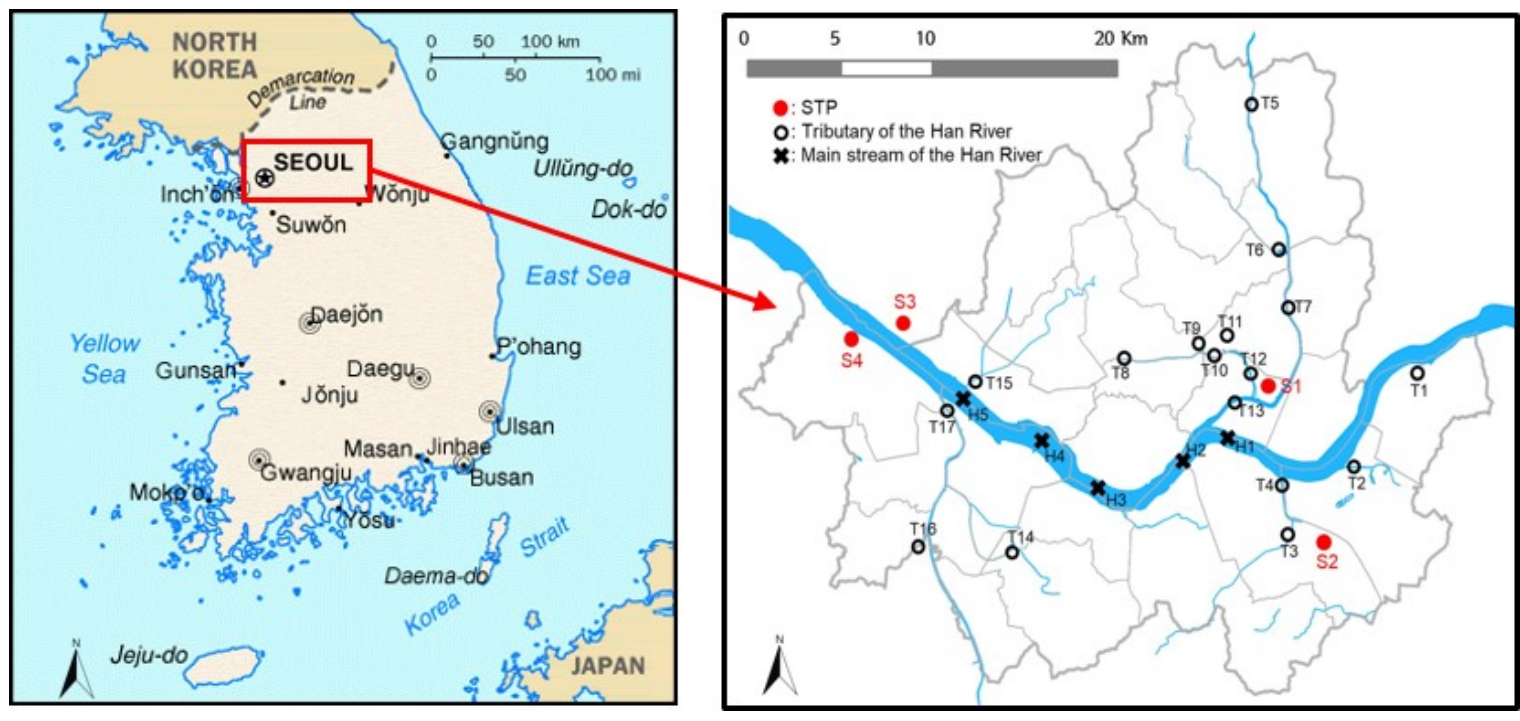

Figure 1. Location of sewage treatment plants and sampling points in the Han River and its tributaries (STP: sewage treatment plant).

Samples were also collected quarterly at 12 locations (5 influents and 7 effluents) in four STPs (STP1-STP4) located in Seoul. The locations of the collection points are shown in Figure 1. The total area served by these STPs is approximately $605 \mathrm{~km}^{2}$. The total treatment capacity of the four STPs is 4.98 million $\mathrm{m}^{3} /$ day; the largest plant (S4) has a capacity of $1,630,000 \mathrm{~m}^{3} /$ day. The total input flow of the four STPs is $4,207,000 \mathrm{~m}^{3} /$ day. These STPs mainly treat domestic wastewater $(99.4 \%)$ with small amounts $(<0.6 \%)$ of industrial wastewater [32]. As shown in Table S1 in the Supplementary Materials, after the primary sewage treatment, including the precipitation stage, each STP applies an advanced biological treatment process (a modified Ludzack-Ettinger (MLE) or anaerobic-anoxicaerobic (A2O) process) to remove organics, nitrogen, and phosphorus. Following the advanced biological treatment processes, a chemical coagulant is applied to reduce the total phosphorus (T-P) $(<0.5 \mathrm{mg} / \mathrm{L})$. The treated sewage water is then discharged to the Han River or its tributaries.

To measure SMF levels in household products, various PCPs were purchased from a supermarket in Seoul and the concentrations of nine SMFs in each product were measured. A total of 36 PCPs, including 10 hair care products (e.g., shampoo), 9 dish detergents, 2 body soaps, 3 hand creams, and 12 perfumes, were collected. The perfumes were liquids, while the rest of the samples were creams and gels. 
Table 1. Physicochemical properties of synthetic musk fragrances (SMFs).

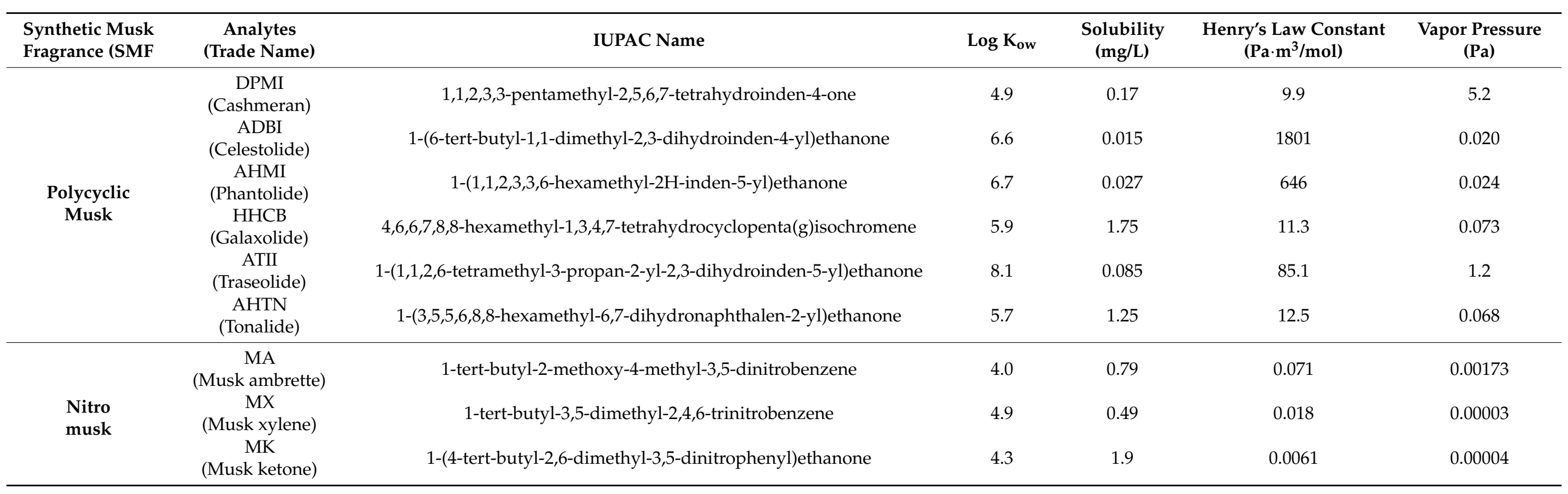




\subsection{Analysis}

The concentrations of the nine SMFs were determined by a combination of headspacesolid phase microextraction (HS-SPME) using a Combi-Pal auto-sampler (CTC Analytics AG, Zwingen, Switzerland) and gas chromatography-mass spectrometry (GC-MS) (QP2010 Plus and QP2020; Shimadzu Corporation, Tokyo, Japan). The SPME fiber was polydimethylsiloxane/divinylbenzen (PDMS/DVB) $(65 \mu \mathrm{m})$ and was purchased from Supelco (Bellefonte, PA, USA). The fiber was pretreated according to the manufacturer's recommendations before use. A $20 \mathrm{~mL}$ screw cap vial sealed with PTFE (polytetrafluoroethylene)silicon was used; for liquid samples, $10 \mathrm{~mL}$ of the sample was placed in a vial to which $3.0 \mathrm{~g} \mathrm{NaCl}$ was added. The vial was sealed and the sample was extracted at $90{ }^{\circ} \mathrm{C}$ for $30 \mathrm{~min}$ at $500 \mathrm{rpm}$. Liquid perfume in the products was diluted with acetone and analyzed without pretreatment. In the case of cream- and gel-type PCPs, a small amount of sample was aliquoted into a headspace vial and analyzed by SPME-GC/MS.

Separation of SMFs was achieved using a DB-1MS column $(30 \mathrm{~m} \times 0.25 \mathrm{~mm} \times$ $0.25 \mu \mathrm{m}$ : Agilent Technologies). The carrier gas was helium (purity $99.9999 \%$ ) and the flow rate was $1.0 \mathrm{~mL} / \mathrm{min}$. The GC oven temperature was increased from $120^{\circ} \mathrm{C}(2 \mathrm{~min})$ to $160{ }^{\circ} \mathrm{C}(3 \mathrm{~min})$ at a rate of $10^{\circ} \mathrm{C} / \mathrm{min}$, and then to $185^{\circ} \mathrm{C} 2.5^{\circ} \mathrm{C} / \mathrm{min}$ and finally $250{ }^{\circ} \mathrm{C}$ (3 $\mathrm{min}$ ) at $30^{\circ} \mathrm{C} / \mathrm{min}$. The total analysis time was $24.17 \mathrm{~min}$. The transfer line and ion source temperature of the mass spectrometer was set to $230^{\circ} \mathrm{C}$. Thermal desorption on the SPME fiber was performed using an injector at $230^{\circ} \mathrm{C}$ in split mode, with a split ratio of 5.0. The mass spectrometer was operated in electron ionization (EI) mode at $-70 \mathrm{eV}$. For identification of SMFs, the EI mass spectrum of the compound eluted from the GC column was compared to the EI mass spectra in the National Institute of Standards and Technology (NIST) v 2.2g (2014) database. The quality assurance and quality control (QA/QC) results are shown in Text S1 and Table S2, and the chromatograms and mass spectra of SMFs are shown in Table S3.

\subsection{Statistics}

For statistical analysis, SPSS Statistics 24 was used (IBM SPSS Statistics: Version 23). We used the statistical significance as a $p$-value of $<0.05$.

\section{Results and Discussion}

\subsection{Synthetic Musk Fragrances in Personal Care Products}

First, an SMF analysis was performed on the PCPs. Table 2 shows the analysis results for 36 PCPs, including shampoo, detergent, and perfume. The most widely detected SMF was found to be HHCB, which was detected with a frequency of $86.1 \%$ among all PCP samples. It was most often detected in hair care products, with a maximum concentration of $4917 \mu \mathrm{g} / \mathrm{g}$ (median, $395.8 \mu \mathrm{g} / \mathrm{g}$ ) (Table 2). HHCB was especially found in all hair care products and perfumes ( $100 \%$ frequency).

The second most frequently detected SMF after HHCB was AHTN, with a maximum concentration of $442.9 \mu \mathrm{g} / \mathrm{g}$ in $47.2 \%$ of all samples (Table 2). Even though $80 \%$ of hair care products contained AHTN, the AHTN concentration in hair care products was much lower than that of HHCB, with a median value of $1.19 \mu \mathrm{g} / \mathrm{g}$. The HHCB and AHTN concentrations in PCPs observed in this study were similar to those reported in previous studies in the United States [33], but much higher than those reported previously in China [26]. 
Table 2. Concentration $(\mu \mathrm{g} / \mathrm{g})$ and detection frequency $(\%)$ of synthetic musk fragrances in personal care products.

\begin{tabular}{|c|c|c|c|c|c|c|c|c|c|c|c|}
\hline Category & $\mu \mathrm{g} / \mathrm{L}$ & DPMI & ADBI & AHMI & ННСВ & ATII & AHTN & MA & MX & MK & Sum \\
\hline \multirow{2}{*}{$\begin{array}{l}\text { Haircare products } \\
\qquad(\mathrm{n}=10)\end{array}$} & Range & N.D. & N.D. -0.83 & N.D. -0.67 & $0.09->4916.99^{a}$ & N.D. -58.85 & N.D. -442.87 & N.D. & N.D. & N.D.-18.76 & $0.13-5012.41$ \\
\hline & Median & N.D. & N.D. & N.D. & 395.82 & N.D. & 1.19 & N.D. & N.D. & N.D. & 455.51 \\
\hline \multirow{3}{*}{$\begin{array}{l}\text { Dishwashing detergent } \\
\qquad(\mathrm{n}=9)\end{array}$} & Range & N.D. & N.D. -0.04 & N.D. -0.02 & N.D.-19.40 & N.D. -0.01 & N.D. -7.10 & N.D. & N.D. & N.D. & N.D.-26.50 \\
\hline & Median & N.D. & N.D. & N.D. & 0.01 & N.D. & N.D. & N.D. & N.D. & N.D. & 0.03 \\
\hline & Frequency (\%) & 0 & 11.1 & 11.1 & 77.8 & 11.1 & 44.4 & 0 & 0 & 0 & \\
\hline \multirow{3}{*}{$\begin{array}{l}\text { Body washes } \\
\qquad(\mathrm{n}=2)\end{array}$} & Range & N.D. & N.D. & N.D. -1.12 & $0.34-0.49$ & N.D. & N.D. & N.D. & N.D. & N.D. & $0.34-1.61$ \\
\hline & Median & N.D. & N.D. & 0.56 & 0.41 & N.D. & N.D. & N.D. & N.D. & N.D. & 0.97 \\
\hline & Frequency (\%) & 0 & 0 & 50 & 100 & 0 & 0 & 0 & 0 & 0 & \\
\hline \multirow{3}{*}{$\begin{array}{l}\text { Hand cream } \\
\qquad(\mathrm{n}=3)\end{array}$} & Range & N.D. & N.D. & N.D. & N.D.-213.95 & N.D. & N.D. & N.D. & N.D. & N.D. & N.D.-213.95 \\
\hline & Median & N.D. & N.D. & N.D. & N.D. & N.D. & N.D. & N.D. & N.D. & N.D. & N.D. \\
\hline & Frequency (\%) & 0 & 0 & 0 & 33.3 & 0 & 0 & 0 & 0 & 0 & \\
\hline \multirow{2}{*}{$\begin{array}{l}\text { Perfume } \\
(\mathrm{n}=12)\end{array}$} & Range & N.D. -21.93 & N.D. & N.D. -0.02 & $0.29->157.73^{a}$ & N.D. -1.69 & N.D. -3.90 & N.D. & N.D. & N.D. -39.25 & $0.29-163.71$ \\
\hline & Frequency (\%) & 41.7 & 0 & 8.3 & 100 & 16.7 & 41.7 & 0 & 0 & 58.3 & \\
\hline \multirow{3}{*}{$\begin{array}{l}\text { Total } \\
(n=36)\end{array}$} & Range & N.D. -18.69 & N.D. -0.83 & N.D. -1.12 & N.D. $->4916.99$ a & N.D. -58.85 & N.D. -442.87 & N.D. & N.D. & N.D. -39.25 & N.D. -5012.41 \\
\hline & Median & N.D. & N.D. & N.D. & 2.44 & N.D. & N.D. & N.D. & N.D. & N.D. & 8.03 \\
\hline & Freq. $\%$ & 13.9 & 8.3 & 13.9 & 86.1 & 19.4 & 47.2 & 0 & 0 & 25 & \\
\hline
\end{tabular}

a: The mass (MS) detector saturated and an accurate value calculation was not available; N.D. indicates less than detection limit. 
The most frequently detected SMF after HHCB and AHTN was MK, which was detected at a maximum concentration of $39.3 \mu \mathrm{g} / \mathrm{g}$ only in perfume and hair care products. Not all PCPs were found to contain MA and MX (Table 2). These results were consistent with the trends of domestic SMF usage reported in Korea, with significantly higher HHCB usage (60.6 tons/year) than AHTN (2.0 tons/year) and MK (11.6 tons/year) in 2006 [9]. Among other SMFs, ATII, AHMI, DPMI, and ADBI were observed with a frequency of less than $20 \%$. In particular, DPMI was only detected at concentrations up to $21.9 \mu \mathrm{g} / \mathrm{g}$ in 5 out of 12 perfume products. Hair care products $(n=10)$ had the highest SMF content per unit weight (median value $455.5 \mu \mathrm{g} / \mathrm{g}$ ), followed by perfume ( $\mathrm{n}=12$; median value, $88.273 \mu \mathrm{g} / \mathrm{g}$ ). Our result implies that the major sources of SMFs in household PCPs, especially HHCB, are hair care products and perfumes; these SMFs can go into sewage treatment plants through domestic sewage when showering or washing one's face at home.

\subsection{Synthetic Musk Fragrances in STP Influents}

The SMF concentrations in the influents of the four STPs were between 3.532 and $11.080 \mu \mathrm{g} / \mathrm{L}$ (median, $6.756 \mu \mathrm{g} / \mathrm{L}$ ) (Table 3). Because more than $90 \%$ of the inflow water to all STPs was domestic sewage, there was no significant difference in SMF concentration between each STP. Five SMFs (HHCB, AHTN, MK, DPMI, and ATII) were most frequently detected in the sewage influents. The highest concentration $(3.200$ to $10.110 \mu \mathrm{g} / \mathrm{L})$ was found for HHCB, with a median value of $6.130 \mu \mathrm{g} / \mathrm{L}$. On a median basis, HHCB accounted for $90.7 \%$ of the total SMFs and was present in significantly higher concentrations than AHTN, MK, and DPMI (Table 3). The AHTN concentration (median, $0.373 \mu \mathrm{g} / \mathrm{L}$ ) was similar to that of MK $(0.352 \mu \mathrm{g} / \mathrm{L})$. The DPMI concentration was half that of AHTN and MK, with a median value of $0.166 \mu \mathrm{g} / \mathrm{L}$. While ADBI was detected intermittently and at low levels, MA and MX were not detected at all in STP influents.

The HHCB concentration in the STP influents in this study was higher than that previously reported in Italy [34], Spain [35,36], France [22], and other studies in Korea [25] (Table S4). This might be due to the characteristics of the STPs, which were located in the densely populated city of Seoul, and most of the STP influents were therefore composed of domestic sewage. However, the AHTN concentration in the STP influent was similar to or lower than that reported in previous studies.

The HHCB/AHTN concentration ratio in the sewage influents was 16.4, which was higher than the previously reported values of 4.5 [25], 1.2 [28], and 3.2 [26], and similar to the value obtained by Tasselli and Guzzella [34]. This result implies that significantly higher amounts of HHCB than AHTN are used in PCPs in Korea. Since Table 2 shows that the HHCB concentration was significantly higher in hair care products (e.g., shampoo) and perfumes, these can be the major source of HHCB in sewage influents.

\subsection{Synthetic Musk Fragrances in the STP Effluents}

The total SMF concentrations in the sewage effluents were in the range $0.949-5.880 \mu \mathrm{g} / \mathrm{L}$, and the median value was $2.945 \mu \mathrm{g} / \mathrm{L}$ (Table 3). The SMF detection frequencies in the STP effluents were similar to those in the STP influents. Among the SMFs, HHCB, AHTN, MK, DPMI, and ATII were detected in most of the samples, while ADBI, AHMI, MA, and MX were not detected. The SMF with the highest concentration was HHCB, with a median value of $2.546 \mu \mathrm{g} / \mathrm{L}$, and a range of $0.701-5.390 \mu \mathrm{g} / \mathrm{L}$. Based on the median value, HHCB accounted for almost $90 \%$ of the total SMFs, and its concentration was several tens of times higher than those of AHTN, MK, and DPMI.

The HHCB concentrations measured in this study were slightly higher than previously reported values in Germany [37], Thailand [24], USA [28], and China [26] (Table S4). The distribution of SMFs in the STP effluents was dependent on the SMF concentrations in the STP influents, removal efficiency, and the chemical properties of each SMF. The relatively higher level of HHCB in the sewage effluents was a consequence of the high concentration in the sewage influents. 
Table 3. Concentration of synthetic musk fragrances in the in the sewage treatment plant (STP) influent, effluent, tributary, and the Han River.

\begin{tabular}{|c|c|c|c|c|c|c|c|c|c|c|c|}
\hline Category & $\mu \mathrm{g} / \mathrm{L}$ & DPMI & ADBI & AHMI & НHСВ & ATII & AHTN & MA & MX & MK & Sum \\
\hline \multirow{3}{*}{$\begin{array}{c}\text { STP } \\
\text { Influent } \\
(n=27)\end{array}$} & Range & $0.034-0.393$ & N.D.- 0.015 & N.D. & $3.200-10.110$ & N.D. -0.090 & $0.012-0.572$ & N.D. & N.D. & $0.148-1.056$ & $3.532-11.08$ \\
\hline & Median & 0.166 & N.D. & N.D. & 6.130 & 0.058 & 0.373 & N.D. & N.D. & 0.352 & 6.756 \\
\hline & Frequency (\%) & 100 & 28 & 0 & 100 & 92 & 100 & 0 & 0 & 100 & \\
\hline \multirow{3}{*}{$\begin{array}{c}\text { STP } \\
\text { Effluent } \\
(\mathrm{n}=35)\end{array}$} & Range & $0.015-0.129$ & N.D. & N.D. & $0.701-5.390$ & N.D. -0.059 & N.D. -0.306 & N.D. & N.D. & $0.055-0.423$ & $0.949-5.880$ \\
\hline & Median & 0.071 & N.D. & N.D. & 2.546 & 0.028 & 0.161 & N.D. & N.D. & 0.218 & 2.945 \\
\hline & Frequency (\%) & 100 & 0 & 0 & 100 & 82.9 & 97.1 & 0 & 0 & 100 & \\
\hline \multirow{3}{*}{$\begin{array}{l}\text { Tributary } \\
(\mathrm{n}=153)\end{array}$} & Range & N.D.-0.131 & N.D. & N.D. & $0.017-2.825$ & N.D. -0.040 & N.D. -0.169 & N.D. & N.D. & $0.005-0.258$ & $0.034-3.392$ \\
\hline & Median & 0.007 & N.D. & N.D. & 0.220 & N.D. & 0.019 & N.D. & N.D. & 0.022 & 0.304 \\
\hline & Frequency (\%) & 52.3 & 0 & 0 & 100 & 46.4 & 82.4 & 0 & 0 & 100 & \\
\hline \multirow{3}{*}{$\begin{array}{l}\text { Han river } \\
(\mathrm{n}=40)\end{array}$} & Range & N.D.- -0.045 & N.D. & N.D. & $0.026-0.705$ & N.D. -0.016 & N.D. -0.046 & N.D. & N.D. & N.D.- -0.074 & N.D. -0.844 \\
\hline & Median & N.D. & N.D. & N.D. & 0.105 & N.D. & 0.010 & N.D. & N.D. & 0.016 & 0.141 \\
\hline & Frequency (\%) & 37.5 & 0 & 0 & 100 & 15.0 & 62.5 & 0 & 0 & 87.5 & \\
\hline
\end{tabular}

N.D. indicates less than detection limit. 
The average removal rate of SMFs in the four STPs using the MLE and A2O processes (Table S2) was $58.5 \%$ for HHCB and $56.8 \%$ for AHTN. The HHCB and AHTN removal efficiencies were lower than the values reported in previous studies $[23,24,37,38]$.

\subsection{Synthetic Musk Fragrances in the Mainstream of the Han River}

Table 3 also shows the concentrations of the nine SMFs $(n=153)$ in five mainstream sites of the Han River (H1-H5) and 17 tributaries (T1-T17), which were measured every month from March to November 2018. Various pollutants are released into the river as it passes through the densely populated area of Seoul. Following treatment in an STP, pollutants can flow into the mainstream and streams of the Han River in the form of STP effluents. In this study, five SMFs (HHCB, MK, AHTN, DPMI, and ATII) were detected in 17 tributaries; the order of both detection frequency and concentration was $\mathrm{HHCB}, \mathrm{MK}$, AHTN, DPMI, and ATII. At all sites, HHCB was detected in samples, but the concentration at each site varied from 0.017 to $2.825 \mu \mathrm{g} / \mathrm{L}$, with a median concentration of $0.220 \mu \mathrm{g} / \mathrm{L}$ (Table 3). As with the STP effluents, ADBI, AHMI, MA, and MX were not detected in the Han River samples.

The median concentrations observed in the Han River were $0.105,0.016$, and $0.010 \mu \mathrm{g} / \mathrm{L}$ for $\mathrm{HHCB}, \mathrm{MK}$, and AHTN, respectively, indicating that $\mathrm{HHCB}$ was also the predominant SMF in river samples. The HHCB concentrations were higher, but the levels of AHTN were similar or lower than those reported in China [39], Singapore [40], and rivers in the Hesse region of Germany [41]. The distribution pattern of SMFs in the mainstream of the Han River was similar to that in the STP influents and effluents (Figure 2). Interestingly, the similar HHCB concentration in the STP effluents compared to those reported in STPs elsewhere indicates that HHCB might be decomposed to a relatively greater extent than in other STPs (Figure 2). Figure 3 shows the HHCB concentrations in samples taken from the STP influents, effluents, tributaries, and mainstream of the Han River. As shown in Figure 3, the SMF concentrations, especially that of HHCB, were significantly decreased in the STP effluents compared to the influents, and there was then a gradual decrease from the tributaries to the mainstream of the Han River. This implied that effective SMF removal occurred during the sewage treatment process, which together with dilution in the river represented the two main removal mechanisms of HHCB.

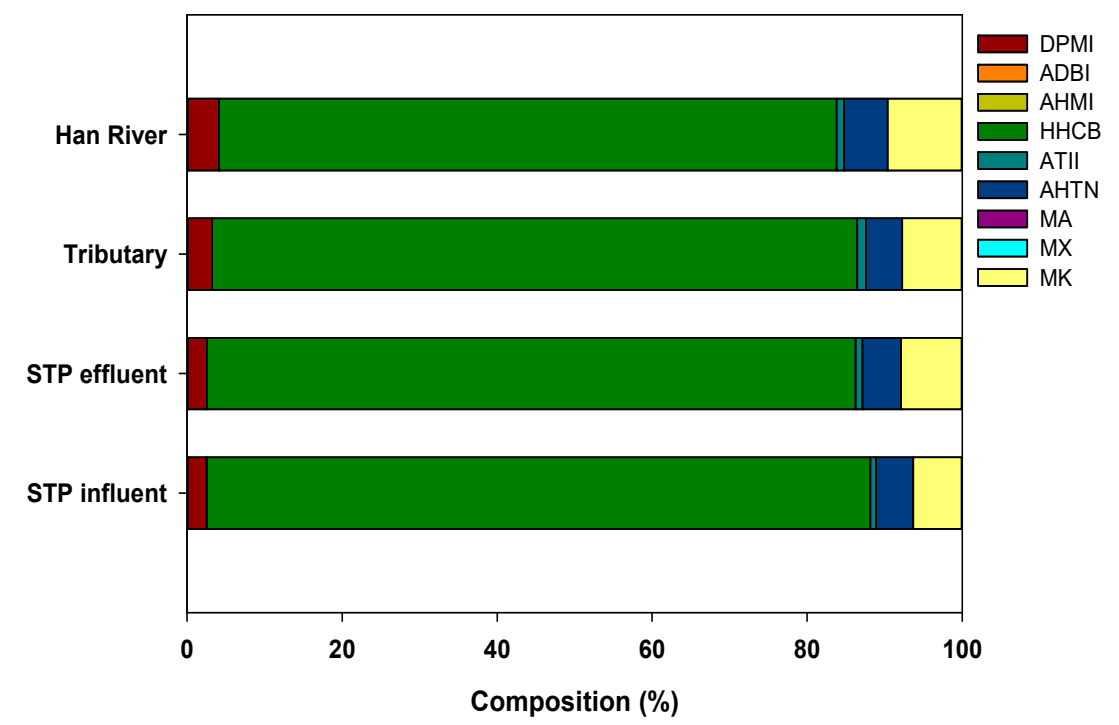

Figure 2. Compositions of synthetic musk fragrances in the STP influent, effluent, tributary, and the Han River. 


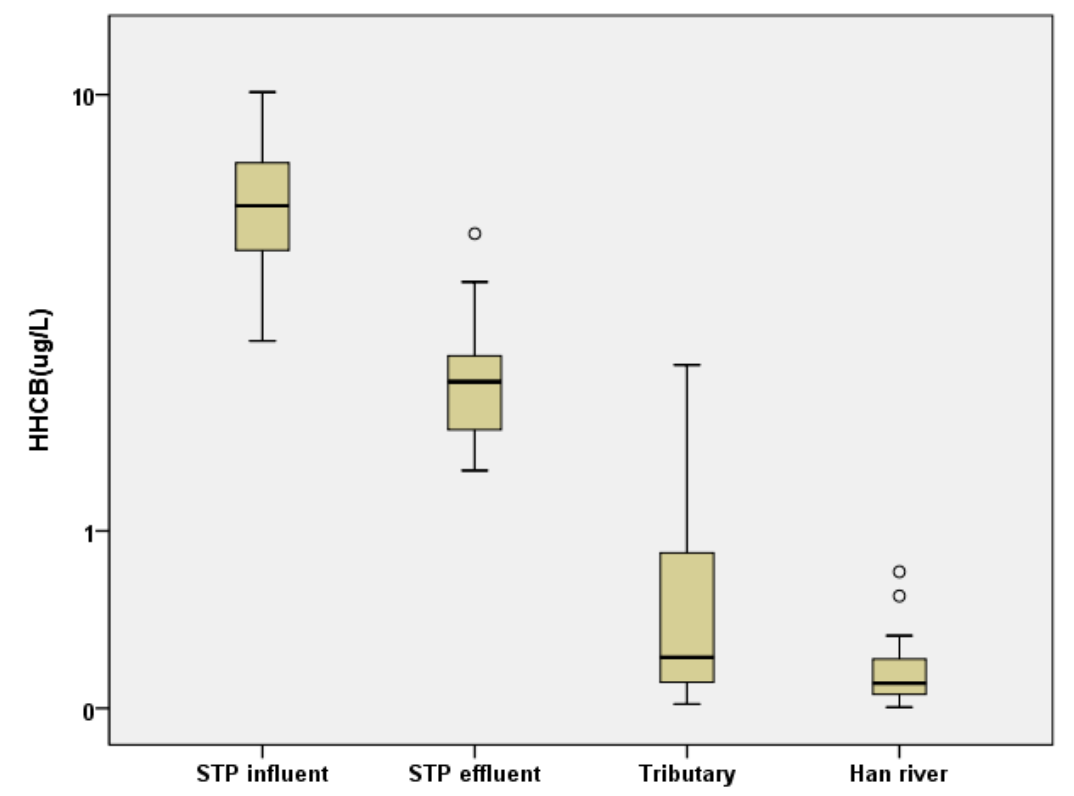

Figure 3. The concentration distribution of HHCB in the samples of STP influent, effluent, tributary, and mainstream of the Han River.

\subsection{Effect of STP Effluents on SMF Concentrations in the Han River}

Figure 4 shows the STP discharge volumes, distance to the nearest sampling site, and SMF concentration at each point. As shown in Figure 4, of the 17 tributaries, a total of 7 sites were affected by the STPs and had high SMF concentrations (Figure 4). The sites with extremely high concentrations (T5, T13, T4, and T16) were located in the region affected by the STP effluents. We found that the SMF concentrations at T13 and H2 increased due to the effluent from S1, and the SMF concentration suddenly increased at point T4 due to the effluent from S2. At T5, a high HHCB concentration was observed due to the presence of two STPs upstream, but the concentration gradually decreased toward T7, which was probably a dilution effect, and then rapidly increased due to the discharge from S1. The results shown in Figure 4 imply that the SMF concentrations in the tributaries were generally higher at sampling sites affected by STP effluents released from upstream locations.

Finally, to examine the effect of sewage effluent discharge on the SMF concentration in the receiving water, two factors, i.e., the ratio of sewage discharge to the river flow rate $(\mathrm{Qw} / \mathrm{Qr})$ and the distance from the sewer outlet to the sampling point $(\Delta \mathrm{L})$, were developed. While there was no correlation between SMF concentration and Qw/Qr, we found that there was a statistically strong relationship $(r=0.850, p<0.05)$ between the $1 / \Delta \mathrm{L}$ value and the SMF concentration in the river. This result implies that the closer the sampling point to the sewage outlet, the higher the SMF concentration in the tributaries or Han River water samples. 


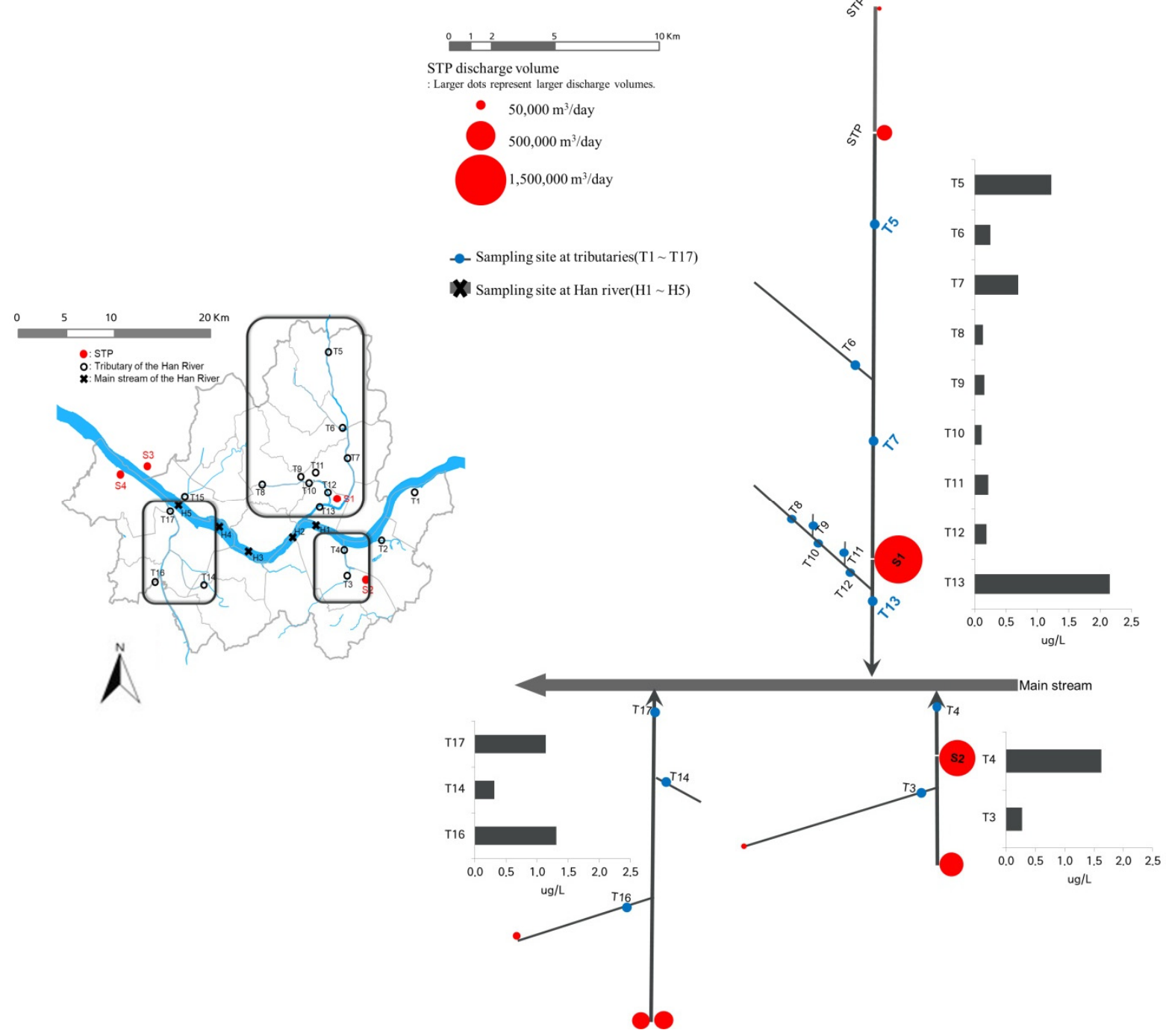

Figure 4. The location of the sampling site in the tributaries and the Han River basin and the average concentration of SMFs at each tributary (red circles represent the effluent volume of STP).

\section{Conclusions}

Nine SMFs were measured in the influents and effluents of four STPs, 17 tributaries, and five sampling sites in the Han River, and also in 36 different PCPs, including hair care products, perfumes, and detergents. In the PCPs, HHCB was the most abundant SMF, while AHTN, MK, AHMI, DPMI, ATII, and ADBI were detected with a frequency of less than 50\%. Among the PCPs, hair care products had the highest SMF content per unit weight, with the highest concentration (median, $395.8 \mu \mathrm{g} / \mathrm{g}$ ) being observed for HHCB. The SMF distribution among the four STP influents was similar to that of PCPs, with a median total SMF concentration of $6.756 \mu \mathrm{g} / \mathrm{L}$ and median HHCB concentration of $6.130 \mu \mathrm{g} / \mathrm{L}$. The median SMF concentration in the effluents was $2.945 \mu \mathrm{g} / \mathrm{L}$, while the median HHCB concentration was $2.546 \mu \mathrm{g} / \mathrm{L}$, and their distribution pattern was similar to that in the sewage influents, although the MK concentration was slightly higher $(0.218 \mu \mathrm{g} / \mathrm{L})$ than that of AHTN $(0.161 \mu \mathrm{g} / \mathrm{L})$. In the sewage treatment process, the removal efficiencies of HHCB, AHTN, and MK were 58.5\%, 56.8\%, and 38.1\%, respectively. In the 17 tributaries and Han River mainstream, five SMFs were detected at levels similar to those in the STP effluents, but the concentrations decreased due to the dilution effect. The HHCB concentration was $0.220 \mu \mathrm{g} / \mathrm{L}$ in tributaries and $0.105 \mu \mathrm{g} / \mathrm{L}$ in the mainstream. The highest SMF concentrations in the tributaries were observed at locations close to the STPs, 
implying that sewage effluents were the main source of SMFs in the receiving water. The results of this study confirmed that the mainource of SMFs in the receiving water was sewage effluents containing untreated SMFs, which largely originate from household PCPs, especially hair care products (e.g., shampoo) and perfumes.

The limitation of this study was that monitoring was not sufficient. More comprehensive monitoring is needed to achieve a clear correlation of SMF levels between the Han River and household personal care products, and to investigate the effect of sewage effluent discharge on SMF concentrations in receiving water. Finally, as a suggestion to reduce the level of SMFs, more effective treatment technologies such as advanced oxidation processes need to be implemented in sewage treatment plants.

Supplementary Materials: The following are available online at https://www.mdpi.com/2073 $-4441 / 13 / 4 / 392 / s 1$, Text S1: Quality assurance and quality control (QA/QC) of synthetic musk fragrances (SMFs), Table S1: Basic information of four sewage treatment plants in highly populated urban area, Table S2: Recoveries, MDL and LOQ values for nine synthetic musk fragrances (SMFs), Table S3: Chromatograms and mass spectra of the SMFs, Table S4: Concentration of synthetic musk fragrances in sewage treatment plant (STP) influents and effluents in other countries.

Author Contributions: Conceptualization, M.-Y.L. and K.-D.Z.; methodology, J.-H.H., J.-H.L. and S.-R.O.; software, J.-H.H.; validation, H.-J.H.; investigation, J.-H.H., H.-J.H., J.-Y.L., S.-R.O., M.-Y.L. and K.-D.Z.; data curation, J.-H.H.; writing—original draft preparation, J.-H.H.; writing-review and editing, M.-Y.L., K.-D.Z. and Y.-M.L.; visualization, J.-H.H. and Y.-M.L.; supervision, M.-Y.L. and K.-D.Z.; project administration, M.-Y.L.; funding acquisition, M.-Y.L. All authors have read and agreed to the published version of the manuscript.

Funding: This study was supported by the Seoul Metropolitan Government Research Institute of Public Health and Environment (SIHE).

Institutional Review Board Statement: Not applicable.

Informed Consent Statement: Not applicable.

Data Availability Statement: Not applicable.

Acknowledgments: We thank all the collaborators who participated in this study. We would like to thank the Jung Rang STP members (Jung-Yeon Lee, Do-Hun Lee, and Young-Hyo Choi) and Water Environment Research Division members (Ye-Duk Choi, Ho-Kyun Yoon, Tae-Ho Lee) for their cooperation in collecting samples.

Conflicts of Interest: The authors declare no conflict of interest.

\section{References}

1. Balk, F.; Blok, H.; Salvito, D. Environmental Risks of Musk Fragrance Ingredients; ACS Publications: Washington, DC, USA, 2001; pp. 168-190. [CrossRef]

2. Kraft, P. Aroma Chemicals IV: Musks. Chemistry and Technology of Flavours and Fragrances; John Wiley \& Sons: Hoboken, NJ, USA, 2009; pp. 143-168. [CrossRef]

3. Marchal, M.; Beltran, J. Determination of synthetic musk fragrances. Int. J. Environ. Anal. Chem. 2016, 96, 1213-1246. [CrossRef]

4. Wong, F.; Robson, M.; Melymuk, L.; Shunthirasingham, C.; Alexandrou, N.; Shoeib, M.; Luk, E.; Helm, P.; Diamond, M.L.; Hung, H. Urban sources of synthetic musk compounds to the environment. Environ. Sci. Process. Impacts 2019, 21, 74-88. [CrossRef] [PubMed]

5. ECCC. Draft Screening Assessment-Nitro Musks Group. 2018. Available online: https://www.canada.ca/en/environmentclimate-change/services / evaluating-existing-substances/draft-screening-assessment-nitro-musks-group.html (accessed on 2 February 2020).

6. Kathryn, M.; Weisskopf, M.; Shine, J. Human exposure to nitro musks and the evaluation of their potential toxicity: An overview. Environ. Health 2014, 13, 14. [CrossRef]

7. Tumová, J.; Šauer, P.; Golovko, O.; Koba Ucun, O.; Grabic, R.; Máchová, J.; Kocour Kroupová, H. Effect of polycyclic musk compounds on aquatic organisms: A critical literature review supplemented by own data. Sci. Total Environ. 2019, 651, 2235-2246. [CrossRef] [PubMed]

8. Lee, I.S.; Kim, U.J.; Oh, J.E.; Choi, M.; Hwang, D.W. Comprehensive monitoring of synthetic musk compounds from freshwater to coastal environments in Korea: With consideration of ecological concerns and bioaccumulation. Sci. Total Environ. 2014, 470-471, 1502-1508. [CrossRef] 
9. Lee, I.; Lee, C.; Huh, S.; Yoon, Y.; Shin, S.; Yoon, J. Development of Analytical Method and Monitoring of Personal Care Products in the Nakdong River System. Available online: https:/ / scienceon.kisti.re.kr/srch/selectPORSrchReport.do?cn=TRKO201300007 728 (accessed on 2 February 2020).

10. Ministry of Environment (MOE) of Korea. The Survey on the Distribution Amount of Chemical Compounds; Ministry of Environment (MOE) of Korea: Sejong, Korea, 2016.

11. Safety NI of C. Results of 2016 Chemical Usage Statistics Survey [WWW Document]. 2016. Available online: https:/ / icis.me.go.kr/ (accessed on 29 October 2020).

12. Kannan, K.; Reiner, J.L.; Se, H.Y.; Perrotta, E.E.; Tao, L.; Johnson-Restrepo, B.; Rodan, B.D. Polycyclic musk compounds in higher trophic level aquatic organisms and humans from the United States. Chemosphere 2005, 61, 693-700. [CrossRef]

13. Schnell, S.; Martin-Skilton, R.; Fernandes, D.; Porte, C. The interference of nitro- and polycyclic musks with endogenous and xenobiotic metabolizing enzymes in carp: An in vitro study. Environ. Sci. Technol. 2009, 43, 9458-9464. [CrossRef]

14. Schreurs, R.H.; Legler, J.; Artola-Garicano, E.; Sinnige, T.L.; Lanser, P.H.; Seinen, W.; Van der Burg, B. In vitro and in vivo antiestrogenic effects of polycyclic musks in Zebrafish. Environ. Sci. Technol. 2004, 38, 997-1002. [CrossRef]

15. Yamauchi, R.; Ishibashi, H.; Hirano, M.; Mori, T.; Kim, J.W.; Arizono, K. Effects of synthetic polycyclic musks on estrogen receptor, vitellogenin, pregnane $\mathrm{X}$ receptor, and cytochrome $\mathrm{P} 450$ 3A gene expression in the livers of male medaka (Oryzias latipes). Aquat. Toxicol. 2008, 90, 261-268. [CrossRef]

16. EC. HHCB Summary Risk Assessment Report; EC: Roma, Italy, 2008.

17. ECHA. AHTN EU Risk Assessment Report; EC: Roma, Italy, 2008. [CrossRef]

18. ECHA. MUSK KETONE Summary Risk Assessment Report; EC: Roma, Italy, 2005.

19. ECHA. MUSK XYLENE Summary Risk Assessment Report; EC: Roma, Italy, 2005.

20. US EPA. TSCA Work Plan Chemical Risk Assessment: HHCB; EPA: Washington, DC, USA, 2014.

21. ECHA. REACH SVHC List; EC: Roma, Italy, 2016.

22. Cavalheiro, J.; Prieto, A.; Monperrus, M.; Etxebarria, N.; Zuloaga, O. Determination of polycyclic and nitro musks in environmental water samples by means of microextraction by packed sorbents coupled to large volume injection-gas chromatography-mass spectrometry analysis. Anal. Chim. Acta 2013, 773, 68-75. [CrossRef]

23. Chase, D.A.; Karnjanapiboonwong, A.; Fang, Y.; Cobb, G.P.; Morse, A.N.; Anderson, T.A. Occurrence of synthetic musk fragrances in effluent and non-effluent impacted environments. Sci. Total Environ. 2012, 416, 253-260. [CrossRef]

24. Juksu, K.; Liu, Y.S.; Zhao, J.L.; Yao, L.; Sarin, C.; Sreesai, S.; Klomjek, P.; Traitangwong, A.; Ying, G.G. Emerging contaminants in aquatic environments and coastal waters affected by urban wastewater discharge in Thailand: An ecological risk perspective. Ecotoxicol. Environ. Saf. 2020, 204, 110952. [CrossRef] [PubMed]

25. Lee, I.S.; Lee, S.H.; Oh, J.E. Occurrence and fate of synthetic musk compounds in water environment. Water Res. 2010, 44, 214-222. [CrossRef] [PubMed]

26. Zhang, X.; Yao, Y.; Zeng, X.; Qian, G.; Guo, Y.; Wu, M.; Sheng, G.; Fu, J. Synthetic musks in the aquatic environment and personal care products in Shanghai, China. Chemosphere 2008, 72, 1553-1558. [CrossRef] [PubMed]

27. Heberer, T. Occurrence, Fate, and Assessment of Polycyclic Musk Residues in the Aquatic Environment of Urban Areas-A Review. Acta Hydrochim. Hydrobiol. 2012, 30, 227-243. [CrossRef]

28. Horii, Y.; Reiner, J.L.; Loganathan, B.G.; Senthil Kumar, K.; Sajwan, K.; Kannan, K. Occurrence and fate of polycyclic musks in wastewater treatment plants in Kentucky and Georgia, USA. Chemosphere 2007, 68, 2011-2020. [CrossRef]

29. Yang, J.J.; Metcalfe, C.D. Fate of synthetic musks in a domestic wastewater treatment plant and in an agricultural field amended with biosolids. Sci. Total Environ. 2006, 363, 149-165. [CrossRef]

30. Reiner, J.L.; Berset, J.D.; Kannan, K. Mass flow of polycyclic musks in two wastewater treatment plants. Arch. Environ. Contam. Toxicol. 2007, 52, 451-457. [CrossRef]

31. Seo, C.D.; Son, H.J.; Lee, I.S.; Oh, J.E. Detection of Synthetic Musk Compounds (SMCs) in Nakdong River Basin. J. Korean Soc. Environ. Eng. 2010, 32, 615-624.

32. Ministry of Environment (MOE) of Korea. Generation and Treatment of Industrial Wastewater; Ministry of Environment (MOE) of Korea: Sejong, Korea, 2020.

33. Reiner, J.L.; Kannan, K. A survey of polycyclic musks in selected household commodities from the United States. Chemosphere 2006, 62, 867-873. [CrossRef]

34. Tasselli, S.; Guzzella, L. Polycyclic musk fragrances (PMFs) in wastewater and activated sludge: Analytical protocol and application to a real case study. Environ. Sci. Pollut. Res. 2020. [CrossRef] [PubMed]

35. Homem, V.; Silva, J.A.; Ratola, N.; Santos, L.; Alves, A. Long lasting perfume e A review of synthetic musks in WWTPs. J. Environ. Manag. 2015, 149, 168-192. [CrossRef] [PubMed]

36. Vallecillos, L.; Borrull, F.; Pocurull, E. On-line coupling of solid-phase extraction to gas chromatography-mass spectrometry to determine musk fragrances in wastewater. J. Chromatogr. A 2014, 1364, 1-11. [CrossRef] [PubMed]

37. Lange, C.; Kuch, B.; Metzger, J.W. Occurrence and fate of synthetic musk fragrances in a small German river. J. Hazard. Mater. 2015, 282, 34-40. [CrossRef] [PubMed]

38. Kupper, T.; Plagellat, C.; Brändli, R.C.; de Alencastro, L.F.; Grandjean, D.; Tarradellas, J. Fate and removal of polycyclic musks, UV filters and biocides during wastewater treatment. Water Res. 2006, 40, 2603-2612. [CrossRef] 
39. Zhang, H.; Bu, Q.; Wu, D.; Yu, G. Polycyclic musks in surface water and sediments from an urban catchment in the megacity Beijing, China. Environ. Pollut. 2020, 263, 114548. [CrossRef]

40. Wang, Q.; Kelly, B.C. Occurrence and distribution of synthetic musks, triclosan and methyl triclosan in a tropical urban catchment: Influence of land-use proximity, rainfall and physicochemical properties. Sci. Total Environ. 2017, 574, 1439-1447. [CrossRef]

41. Quednow, K.; Püttmann, W. Organophosphates and synthetic musk fragrances in freshwater streams in Hessen/Germany. Clean Soil Air Water 2008, 36, 70-77. [CrossRef] 